\title{
Review of Cryogenic Carbon Capture Innovations and Their Potential Applications
}

\author{
Carolina Font-Palma * ${ }^{\mathbb{D}}$, David Cann and Chinonyelum Udemu \\ Department of Engineering, University of Hull, Hull HU6 7RX, UK; d.g.cann@hotmail.com (D.C.); \\ C.M.UDEMU-2020@hull.ac.uk (C.U.) \\ * Correspondence: c.font-palma@hull.ac.uk
}

check for updates

Citation: Font-Palma, C.; Cann, D.; Udemu, C. Review of Cryogenic Carbon Capture Innovations and Their Potential Applications. C 2021, 7, 58. https://doi.org/10.3390/ c7030058

Academic Editor: Salvador Ordóñez García

Received: 21 June 2021

Accepted: 26 July 2021

Published: 29 July 2021

Publisher's Note: MDPI stays neutral with regard to jurisdictional claims in published maps and institutional affiliations.

Copyright: (C) 2021 by the authors. Licensee MDPI, Basel, Switzerland. This article is an open access article distributed under the terms and conditions of the Creative Commons Attribution (CC BY) license (https:// creativecommons.org/licenses/by/ $4.0 /)$.

\begin{abstract}
Our ever-increasing interest in economic growth is leading the way to the decline of natural resources, the detriment of air quality, and is fostering climate change. One potential solution to reduce carbon dioxide emissions from industrial emitters is the exploitation of carbon capture and storage (CCS). Among the various $\mathrm{CO}_{2}$ separation technologies, cryogenic carbon capture (CCC) could emerge by offering high $\mathrm{CO}_{2}$ recovery rates and purity levels. This review covers the different CCC methods that are being developed, their benefits, and the current challenges deterring their commercialisation. It also offers an appraisal for selected feasible small- and large-scale CCC applications, including blue hydrogen production and direct air capture. This work considers their technological readiness for CCC deployment and acknowledges competing technologies and ends by providing some insights into future directions related to the R\&D for CCC systems.
\end{abstract}

Keywords: cryogenic carbon capture; desublimation; blue hydrogen

\section{Introduction}

The continuous search for economic growth is causing the decline of natural resources, the detriment of air quality, and is fostering climate change. These effects have at last been taken seriously, which has led to new targets to reduce our impact on the planet. Achieving net zero emissions, as set by the UK, France, Denmark and New Zealand to be by 2050 and in Sweden by 2045, will need the exploitation of carbon capture, utilisation, and storage (CCUS) more than ever. This has been reaffirmed in the recent UK government plan for a green industrial revolution, which aims to make two CCUS industrial clusters operational by the mid-2020s and capture $10 \mathrm{Mt}$ of carbon dioxide a year by 2030 [1]. Figure 1 shows the different $\mathrm{CO}_{2}$ separation technologies that are currently available. Carbon capture has focused on mature technologies, such as chemical absorption using amine-based solvents, but the large volumes of solvent that are used require significant thermal energy for regeneration. This shortcoming is promoting research on emerging technologies including membranes, calcium looping, catalysed sorbents, algae-based capture, direct air capture, and liquefaction [2], but most of these technologies face different technological challenges and are at different and/or lower technology readiness levels.

Low temperature $\mathrm{CO}_{2}$ capture technologies, often called cryogenic carbon capture, relies on phase change, thus separating the $\mathrm{CO}_{2}$ from the gas in the form of a liquid or solid [3]. The definition of 'cryogenics' refers more strictly to the processes that occur at temperatures below $120 \mathrm{~K}$, e.g., in the condensation of nitrogen and oxygen, whilst above $120 \mathrm{~K}$ typically refers to conventional refrigeration; however, the term is often used to imply low temperature separation [4]. Thus, the review of cryogenics below $120 \mathrm{~K}$ is outside the scope of this work dedicated to $\mathrm{CO}_{2}$ applications, and they have been extensively reviewed for the liquefaction of natural gas [5] and air separation units (ASU) that use multi-column cryogenic distillation to generate oxygen, nitrogen and argon elsewhere [6]. The low temperature or cryogenic separation process has been less popular because of it is too expensive or energy intensive or because it has a restricted range of potential 
applications. This method offers various benefits such a high purity product, avoids the need for toxic chemicals, and can be applied to a range of $\mathrm{CO}_{2}$ concentrations. Thus, this work aims to critically assess the different cryogenic technical options for carbon capture, and in particular, presents its potential small- and large-scale applications in order to draw recommendations and future directions.

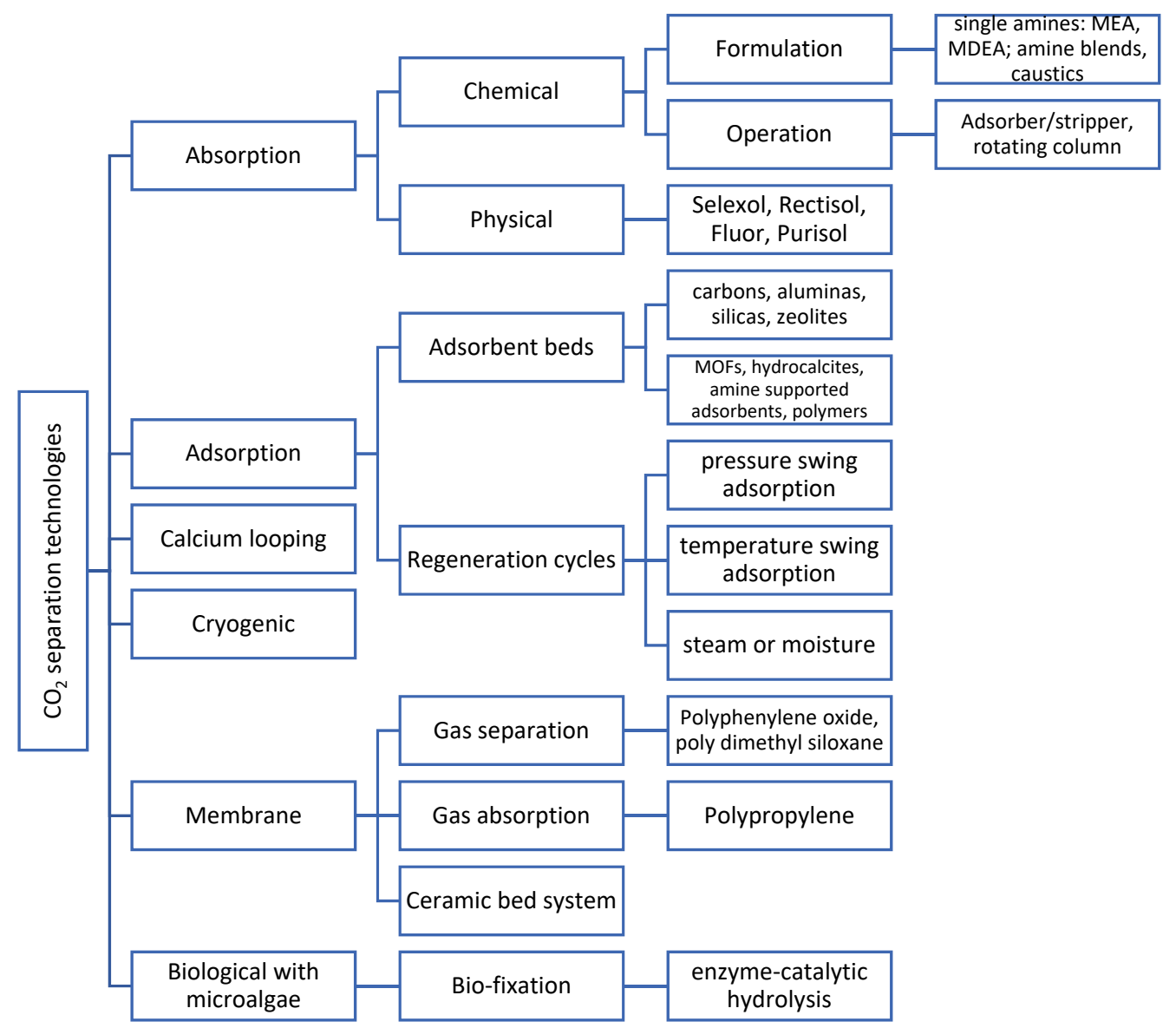

Figure 1. $\mathrm{CO}_{2}$ separation technologies. Adaptation from Babar, Bustam, Ali, Shah Maulud, Shafiq, Mukhtar, Shah, Maqsood, Mellon and Shariff [7], Ben-Mansour, Habib, Bamidele, Basha, Qasem, Peedikakkal, Laoui and Ali [8].

\section{Novelty and Research Strategy}

This work reviews peer-reviewed journal papers and other peer-reviewed sources such as reports, thesis dissertations, book chapters, and conference proceedings within a period from 2010 to May 2021. Scopus and Web of Science Several were used as recognised databases to access the resources. This study reviews the advances and opportunities that cryogenic carbon capture (CCC) offers to mitigate $\mathrm{CO}_{2}$ emissions and to its potential applications should the technology reach a commercialization stage. Table 1 presents the strategy for the literature search grouped by categories and by using the indicated keywords. It was found the largest publication activity was from Brigham Young University, Universiti Teknologi Petronas, and the University of Tsukuba. Any unrelated source was eliminated, leaving a total of 92 articles. A total of three review papers have previously covered some aspects of cryogenic carbon capture: (i) Berstad, Anantharaman and Nekså [3] presented a review of carbon capture methods and technologies, including low temperature methods with more emphasis for the treatment of oxy-derived flue gases by partial condensation or distillation; $\mathrm{CO}_{2}$ desublimation was briefly reviewed; (ii) Maqsood, Mullick, Ali, Kargupta and Ganguly [9] provided a clear distinction between conventional and emerging cryogenic $\mathrm{CO}_{2}$ separation technologies; and (iii) a more recent work from Song, Liu, Deng, $\mathrm{Li}$ and Kitamura [2] offered an updated review of CCC methods with particular emphasis on 
the treatment of fossil fuel combustion sources. However, in order to compete with more mature options, CCC would need to overcome challenges related to the availability of cold energy sources, capture costs, and impurities. Thus, this work explores applications for CCC beyond the treatment of coal-fired and/or natural gas sources. This paper reviews applications that best fit CCC systems for both small-scale applications such as biogas upgrading and onboard carbon capture as well as for large-scale applications such as blue hydrogen production.

Table 1. Search categories and keywords.

\begin{tabular}{ccc}
\hline Category & Keywords & Total Articles \\
\hline cryogenic separation & $\begin{array}{c}\text { cryogenic carbon capture, } \mathrm{CO}_{2} \\
\text { desublimation, } \mathrm{CO}_{2} \text { anti-sublimation, } \\
\text { cryogenic } \mathrm{CO}_{2} \text { separation } \\
\text { blue hydrogen }\end{array}$ & $62^{1}-73^{2}$ \\
& $\begin{array}{c}\text { Cryogenic purification, cryogenic } \\
\text { separation, hydrogen separation }\end{array}$ & $19^{1}-10^{2}$ \\
\hline
\end{tabular}

${ }^{1}$ Scopus, ${ }^{2}$ Web of Science.

\section{Types of Systems for Cryogenic Carbon Capture}

Cryogenic carbon capture involves a physical separation process based on the differences between the boiling points and the desublimation properties of the components in the gas mixture. Therefore, phase equilibria data are indispensable to define the pressure- the temperature conditions in which the $\mathrm{CO}_{2}$ in a mixture remains as a liquid, gas or solid. Figure 2 illustrates the dew and bubble curves and solid-vapour data for $\mathrm{CO}_{2}-\mathrm{CH}_{4}$ mixtures with varying $\mathrm{CO}_{2}$ content. The two regions provide two different types of cryogenic methods: liquid-vapour separation, or conventional cryogenic methods (above $193 \mathrm{~K}$ ), and solid-vapour separation, or nonconventional methods (the region under the black solid curve) [2]. Figure 3 shows the existing and emerging methods for cryogenic carbon capture, which will be discussed further. There are also hybrid technologies not discussed here that can be found elsewhere [9]. Since cryogenic separation offers high $\mathrm{CO}_{2}$ recovery rates and purity levels, this technology is gaining considerable attention.

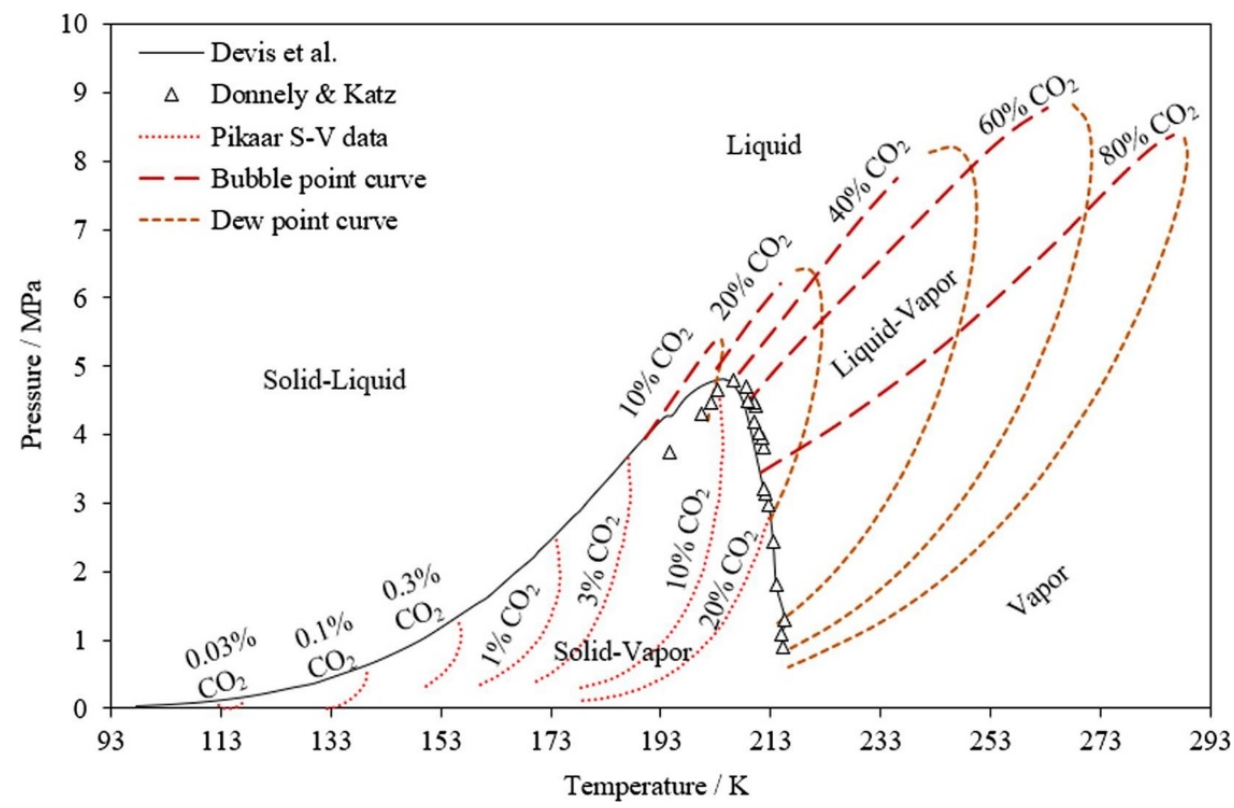

Figure 2. Effect of $\mathrm{CO}_{2}$ concentration on P-T conditions [7] "Reprinted from Cryogenics, Vol 102, Babar, et al., Thermodynamic data for cryogenic carbon dioxide capture from natural gas: A review, Page 88, Copyright (2021), with permission from Elsevier". 


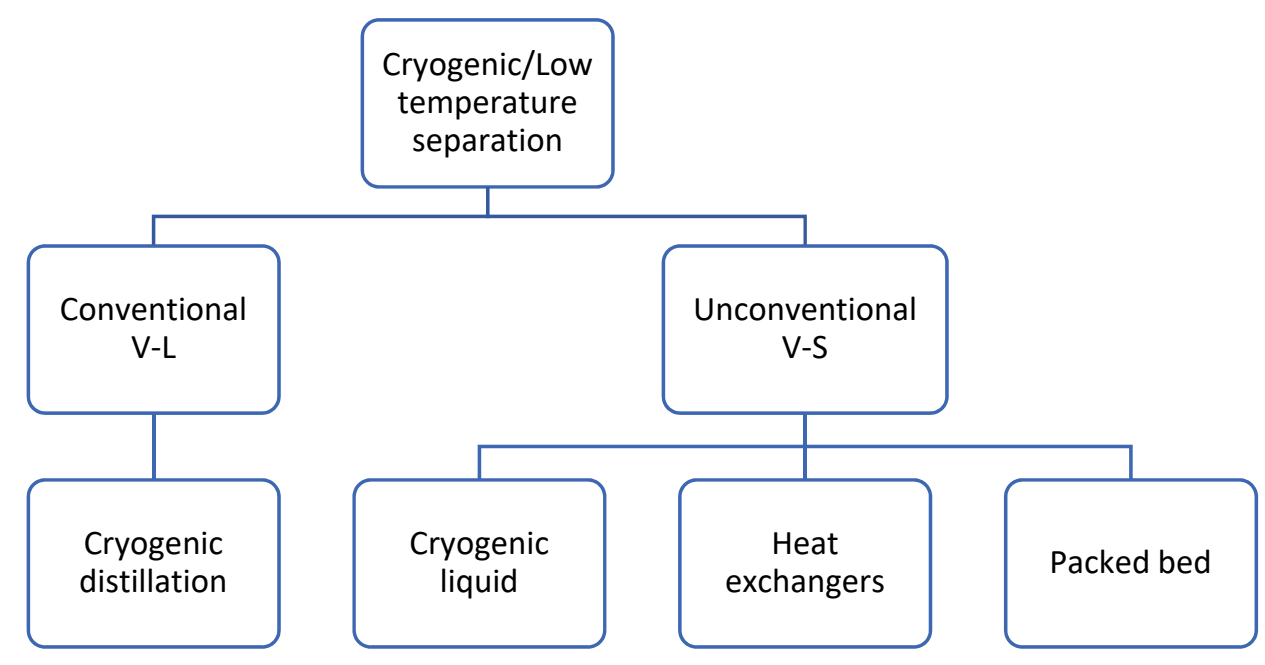

Figure 3. Cryogenic carbon capture technologies. Adaptation from [7].

\subsection{Conventional V-L Separation}

Cryogenic distillation is a well-established technology that achieves separation based on the different boiling points of $\mathrm{CO}_{2}$ and the gas components in the mixture. This method has been used for natural gas purification, where the $\mathrm{CO}_{2}$ is removed in the liquid phase. However, it is an energy-intensive method due to the high pressure employed and the requirement that solid formation be avoided to protect equipment and prevent clogging. To avoid $\mathrm{CO}_{2}$ solidification, extractive distillation, or "Ryan Holmes" technology, makes use of heavier hydrocarbons (e.g., ethane), which increases the solubility of $\mathrm{CO}_{2}$ in the liquid phase, operating temperature, and relative volatility, facilitating separation [10].

Gas-to-liquid carbon dioxide separation is well recognized as the advanced technology for the purification and compression of $\mathrm{CO}_{2}$ captured in oxy-combustion. $\mathrm{A} \mathrm{CO}_{2}$-rich flue gas derived from oxy-combustion is ideal for integration with a carbon dioxide purification unit (CPU) for low temperature $\mathrm{CO}_{2}$ separation. Previous work has evaluated $\mathrm{CO}_{2}$ removal in a two-stage compression at approximately 15 and 30 bar and by the partial condensation and separation of the resulting vapour and liquid phases [11]. The required purity and recovery are accomplished by the fine-tuning of the operating temperatures and pressures and the inclusion of additional flash separation stages to remove the lower boiling point $\mathrm{O}_{2} / \mathrm{N}_{2} / \mathrm{Ar}$ components [12]. For a high purity $\mathrm{CO}_{2}$ product for enhanced oil recovery (EOR) applications, in addition to the flash separation stages, a further stripping column is needed to reduce the oxygen content to $100 \mathrm{ppm}$ [11]. This low temperature separation method is recommended for streams with a $\mathrm{CO}_{2}$ concentration higher than $50 \%$ to limit refrigeration and energy consumption. The other shortcoming is that a CPU requires expensive methods to reduce water content to trace levels to avoid plugging caused by ice, the formation of solid $\mathrm{CO}_{2}$ on the heat exchanger surface, and/or an increase in the pressure drop [13].

\subsection{Unconventional V-S Separation}

The relatively large energy requirements of conventional cryogenic distillation make vapour-solid (V-S) separation an attractive solution. A study that compared the two options found that for a gas mixture with a concentration of $70 \%$ vol. $\mathrm{CO}_{2}$, the energy requirement for a conventional extractive cryogenic distillation network was $1472 \mathrm{~kJ} / \mathrm{kg}$ $\mathrm{CO}_{2}$, and the energy requirement for a cryogenic packed bed was $810 \mathrm{~kJ} / \mathrm{kg} \mathrm{CO}_{2}$ [14].

Low-temperature carbon capture based on solid-vapour equilibria takes advantage of solid formation, which is undesirable in cryogenic distillation and requires reaching temperatures at which $\mathrm{CO}_{2}$ will frost. Achieving desublimation conditions entails contact with a cold medium; therefore, different options to attain the cold conditions that are needed are presented here. 


\subsubsection{Heat Exchangers for Cryogenic Separation}

Heat exchangers are key unit operations for cryogenic industrial applications, such as process cooling, the separation and distillation of gas mixtures, and liquefaction for transportation and storage. The overall energy performance of the system is mostly assessed based on the requirements of the compressors. Therefore, cryogenic heat exchangers are designed to operate with high effectiveness with relatively small temperature differences to compensate for the large heat transfer areas needed and high initial costs. This leads to high manufacturing and installation costs as well as the need for cost-effective heat exchangers to limit the range of the heat exchangers that could be used. Heat exchangers for cryogenic applications include coil-wound heat exchangers used in industrial air liquefaction; plate heat exchangers, including multi-stream plate fin heat exchangers (MPFHE); and regenerative heat exchangers, which are more compatible with energy storage technologies [15].

For the cryogenic separation of $\mathrm{CO}_{2}$ using heat exchangers, a system that employs three heat exchangers was developed [16]. The first heat exchanger precools the rich $\mathrm{CO}_{2}$ stream down to $-100^{\circ} \mathrm{C}$, with a colder lean $\mathrm{CO}_{2}$ stream of $-125^{\circ} \mathrm{C}$ in a gas/gas brazed heat exchanger. The other two act as an intermittent frosting process to capture $\mathrm{CO}_{2}$ solids on the fins of the heat exchange at a temperature between -100 and $-120^{\circ} \mathrm{C}$ and as a $\mathrm{CO}_{2}$ defrosting process using a heating stream at $-50{ }^{\circ} \mathrm{C}$ to recover liquid and gas $\mathrm{CO}_{2}$. Due to frost growth during the frosting step, the defrosting process is needed to maintain acceptable pressure losses on the gas-side circulation. Thus, a thermal swing process is employed, which switches between frosting and defrosting conditions, which can cause challenges for continuous operation. In addition, the $\mathrm{CO}_{2}$ frost layer on heat exchanger surface affects the heat transfer, requiring more cooling and thus reducing its efficiency.

\section{Stirling Coolers}

Song, Kitamura, Li and Ogasawara [17] proposed the use of Stirling coolers in a cryogenic $\mathrm{CO}_{2}$ capture system. The system makes use of three Stirling coolers (SC). The first one is used to precool the feed gas to condense moisture. The second SC is the freezing tower, where the $\mathrm{CO}_{2}$ freezes, and the third $\mathrm{SC}$ is used for cryogenic $\mathrm{CO}_{2}$ storage. The attained specific energy consumption with a $\mathrm{CO}_{2}$ recovery of $95 \%$ is estimated as $2.62 \mathrm{MJ}_{\mathrm{el}} / \mathrm{kg} \mathrm{CO}$ and is reduced to $1.37 \mathrm{MJ} \mathrm{el} / \mathrm{kg} \mathrm{CO}_{2}$ with heat integration, including the capture and compression work [18]. Thus, this system suffers similar issues with the growth of the $\mathrm{CO}_{2}$ frost layer as the use of heat exchangers.

\subsubsection{Cryogenic Liquids}

As an alternative to heat exchangers, the flue gas containing $\mathrm{CO}_{2}$ can be directly contacted with a cryogenic liquid, causing the flue gas to form solid $\mathrm{CO}_{2}$ particles in a staged desublimating column. The $\mathrm{CO}_{2}$ that is dissolved in the contacting liquid will form a slurry, which then goes through filtration and will subsequently provide a $\mathrm{CO}_{2}$ pure product $[19,20]$. The contact liquid is used to provide cooling by direct contact whilst preventing $\mathrm{CO}_{2}$ from freezing on surfaces and to aid in the transport of frost $\mathrm{CO}_{2}$ as a slurry. Isopropane has been chosen based on holding low the vapour pressures need to be to minimise losses by evaporation [20]. Since solid $\mathrm{CO}_{2}$ is filtered, the contact liquid can be recycled with the aim of creating a closed loop, and only a slight loss of contact liquid is anticipated. The direct liquid-gas contact can be achieved through a bubbling column for pilot-scale applications, a spray tower for larger or full industrial-scale applications, or a fluidised bed column with the potential for large-scale application but that has not been tested yet [19]. Through modelling work, it an energy penalty of $0.74 \mathrm{MJ} \mathrm{el} / \mathrm{kg} \mathrm{CO}_{2}$ with $90 \% \mathrm{CO}_{2}$ capture was reported.

Cryogenic carbon capture with an external cooling loop (CCC-ECL) uses heat exchange to desublime $\mathrm{CO}_{2}$ frost. The flue gas first passes through a dryer that removes the water content from the flue gas, the dry flue gas then passes through a heat exchanger and is mixed with a contact liquid, where $99 \%$ of the $\mathrm{CO}_{2}$ is desublimed out of the gas phase. The heat exchanger cooling is supplied via an external cooling loop refrigerant. 
After the $\mathrm{CO}_{2}$ solid is separated from the gas stream and the contact liquid, the $\mathrm{CO}_{2}$ solid stream is pressurised to $70-80$ bar. After this compression stage, the $\mathrm{CO}_{2}$ solid stream and the $\mathrm{CO}_{2}$ lean gas stream pass through a second heat exchanger, which provides energy recovery to the ECL refrigerant and melts the $\mathrm{CO}_{2}$ solid stream into a high pressure liquid stream $[21,22]$. The CCC-ECL process overcomes some of the limitations of heat exchangers, such as the reduction of the rate of heat transfer due to the $\mathrm{CO}_{2}$ frost layer formation on the heat exchanger surface. The solid handling is improved by forming a slurry of contact liquid with solid $\mathrm{CO}_{2}$; however, this process depends on the selection of the contact liquid, which should have a low vapor pressure to avoid loss via evaporation as well as not pose environmental or human harm.

\subsubsection{Packed Beds}

Packed beds filled with cold bed material have been used as a heat transfer surface for $\mathrm{CO}_{2}$ capture [14,23]. Cryogenically cooled nitrogen gas is fed into the packed bed to precool bed material as a cooling step. Once the precooling step is complete, the nitrogen cooling gas flow is stopped, and a simulated flue gas containing $\mathrm{CO}_{2}$ is fed into the packed column. When the flue gas containing $\mathrm{CO}_{2}$ is sufficiently cooled by the bed material, the $\mathrm{CO}_{2}$ desublimates onto the surface of the bed material to form a frost. The $\mathrm{CO}_{2}$ frost will continue to grow on the surface of the bed material until the bed material reaches saturation. When the bed material becomes saturated, the $\mathrm{CO}_{2}$ frost will begin to form on the fresh bed material that is further into the capture column. This leads to a frost front that advances through the packed column. The rate at which the frost front advances through the column is called the frost front velocity. The capture column is saturated with $\mathrm{CO}_{2}$ frost when the frost front advances through the capture column and requires a regeneration step to remove the $\mathrm{CO}_{2}$ frost from the packed bed. Tuinier et al. [24] performed a numerical study of three packed beds operating in parallel cycling between the capture, regeneration, and cooling steps to create a pseudo-continuous process. The cooling duty is dependent on the initial bed temperature and the concentration of $\mathrm{CO}_{2}$ in the flue gas but typically ranges between 1.2-2.6 $\mathrm{MJ}_{\mathrm{el}} / \mathrm{kg} \mathrm{CO}_{2}$ [24].

\section{Moving Packed Beds}

Willson et al. [25] proposed the use of a moving packed bed of cold bed material to capture $\mathrm{CO}_{2}$ without using multiple packed beds operating in cycles. The moving packed bed captures $\mathrm{CO}_{2}$ frost on the surface of the bed material. Bed material is drawn out of the capture column using a screw conveyor and transported into a sublimation unit, the $\mathrm{CO}_{2}$ frost is sublimed and captured for later storage, and the bed material is recirculated into a bed precooler unit and back into the capture column. This operation prevents the excessive accumulation of $\mathrm{CO}_{2}$ frost within the capture column. The moving bed capture process has been experimentally demonstrated with proposed further work to integrate the cooling and regeneration steps into the moving bed, but this has not been tested yet [26].

The estimated specific energy of $\mathrm{CO}_{2}$ capture was calculated by Willson et al. for a number of different applications, the most effective application being biogas upgrading with a specific energy of $263 \mathrm{kWh} /$ tonne $\mathrm{CO}_{2}\left(0.95 \mathrm{MJ} / \mathrm{kg} \mathrm{CO}_{2}\right)$ [25].

\subsubsection{Other Methods \\ Compressed Flue Gas}

Cryogenic carbon capture with compressed flue gas (CCC-CFG) moderately compresses the flue gas to 5-7 bar before heat exchange and expands the flue gas after heat exchange to desublime $\mathrm{CO}_{2}$ frost [27]. This process uses a dryer to remove water content from the flue gas and then uses a heat exchanger to desublime $\mathrm{CO}_{2}$. Similar to the CCC-ECL process, the heat exchanger recovers energy using the pressurised solid $\mathrm{CO}_{2}$ stream, which cools the incoming flue gas, and the solid $\mathrm{CO}_{2}$ melts. This heat exchange step sufficiently cools the flue gas to desublime approximately $75 \%$ of $\mathrm{CO}_{2}$ out of the gas phase. After the expansion of the compressed flue gas, $99 \%$ of the $\mathrm{CO}_{2}$ is separated out of the gas phase. 
Table 2 compares different CCC technologies including other carbon capture technologies such as absorption, adsorption, and membranes. It is shown here that CCC provides a competitive energy duty compared to a range of available CCS technologies, whilst membrane separation provides the most attractive energy duty through the use of vacuum configurations as the driving force [28]. CCC technologies are still in various stages of technological readiness level (TRL) and require further development and large-scale demonstrations to increase confidence in the technology.

Table 2. Comparison of energy duties for various carbon capture technologies.

\begin{tabular}{ccc}
\hline Carbon Capture Method & Energy Duty $\left(\mathbf{M J} / \mathbf{k g C O}_{\mathbf{2}}\right.$ ) & Reference \\
\hline Cryogenic liquids & 0.74 (electrical) & {$[19]$} \\
Stirling coolers & 1.37 (electrical) & {$[18]$} \\
Cryogenic distillation & 1.47 & {$[14]$} \\
Cryogenic packed bed & $1.2-2.6$ (electrical) & {$[24]$} \\
Cryogenic moving bed & 0.95 & {$[25]$} \\
Absorption & $0.87-4.2$ & {$[29]$} \\
Adsorption & $0.36-4.2$ & {$[30]$} \\
Membranes & $0.239-1$ & {$[28]$} \\
Oxy-Fuel combustion & $1.15-2.02$ & {$[30]$} \\
\hline
\end{tabular}

CCC is not a universally applicable technology; however, there are feasible applications where cryogenic separation is advantageous compared to other technologies. The most feasible applications where cryogenic separation is advantageous are discussed next.

\section{Feasible Applications for Cryogenic Separation}

\subsection{Small-Scale Applications}

\subsubsection{Shipping Decarbonisation}

The recognition that the maritime sector emits about $3.1 \%$ of global GHG emissions has helped the International Maritime Organization (IMO) commit to reduce $\mathrm{CO}_{2}$ emissions from international shipping by at least $40 \%$ by 2030 and by at least $50 \%$ by 2050 compared to 2008 emissions [31]. Among the different options to reduce the emissions of GHGs from the shipping sector, e.g., fuel switching to LNG or alternative fuels such as biofuels, methanol, and hydrogen, have been proposed [32]. Balcombe, Brierley, Lewis, Skatvedt, Speirs, Hawkes and Staffell [32] concluded that decarbonisation using LNG will require a combination of efficiency measures to achieve the target of a 50\% reduction of GHG emissions, and bio-based fuels that struggle to prove sustainable source availability will rely more on efficiency measures to reduce their consumption. Thus, exhaust gas treatment via carbon capture offers advantages to avoid changes in engines.

An onboard carbon capture and storage (OCCS) system is a solution to treat exhaust gases emitted from the internal combustion engines on board of ships. The stored $\mathrm{CO}_{2}$ can be unloaded at ports and is then stored underground or undergoes methanation [33].

OCCS offers an option that avoids changes to or the replacement of ship engines. However, most of the literature on carbon capture for shipping applications is related to chemical adsorption using amine-based solvents. For example, Feenstra, Monteiro, van den Akker, Abu-Zahra, Gilling and Goetheer [34] proposed solvent-based carbon capture in diesel and LNG-fuelled vessels (1280 kW dual fuel Wärtsilä 8L20DF and $3000 \mathrm{~kW}$ Wärtsilä 6L34DF). They used MEA as a reference case, which was evaluated against $30 \mathrm{wt} . \%$ aqueous piperazine (PZ). PZ showed lower costs compared to MEA cases due to the higher pressure used in the desorption process and the consequently lower $\mathrm{CO}_{2}$ compression costs. They concluded after an evaluation of equipment weight with stored $\mathrm{CO}_{2}$ that the carbon capture unit could be fit onboard the ship following space reconfiguration. Awoyomi, Patchigolla and Anthony [35] proposed scrubbing using aqueous ammonia for the simultaneous $\mathrm{CO}_{2}$ capture and the removal of $\mathrm{SO}_{2}$ from the flue gas from a 10,800 kW Wärtsilä 9L46F marine diesel engine. Through waste heat recovery, they found that a $70 \% \mathrm{CO}_{2}$ capture rate at $85 \%$ 
load is achievable. They showed that a $75 \%$ carbon capture rate is possible to recover heat using the WHRS (waste heat recovery system) for use in the reboiler (ammonia requires less heat for regeneration than MEA), but $12.88 \%$ more fuel was needed to deliver the same power output of $8.7 \mathrm{MWe}$ at an $85 \%$ load due to the power requirements for $\mathrm{CO}_{2}$ capture and compression for storage.

Thus, the potential for OCCS using chemical solvents has encouraged the exploration of cryogenic carbon capture. As an example, the advanced cryogenic carbon capture (A3C) process has been evaluated for shipping applications. Two case studies were assessed: an LNG fuelled pure car and truck carrier $(12,614 \mathrm{~kW}$ dual-fuel 7S60ME-C10.5-GI two stroke diesel engine) and a hybrid diesel (1200 kW engine that burns marine gas oil, $\mathrm{MGO}$ )-electric/battery ferry. The study found that the integration of the $\mathrm{A} 3 \mathrm{C}$ process into new built or retrofitted vessels is feasible. However, the A3C process showed an impact on the total fuel consumption, which increased by $17 \%$ for LNG and by $24 \%$ for MGO when capturing $90 \%$ of carbon emissions from the main and the auxiliary engines and an additional load on the vessel by the liquid $\mathrm{CO}_{2}$ storage tanks. The report concludes that the cost of the $\mathrm{A} 3 \mathrm{C}$ process for shipping could be up to $50 \%$ lower than the conversion of vessels to use zero carbon fuels [36]. More recently, Chart Industries Inc. acquired Sustainable Energy Solutions (SES), and they have signed an agreement with the Norwegian company TECO 2030 to jointly develop an OCCS solution using Cryogenic Carbon Capture ${ }^{\mathrm{TM}}$ (CCC) technology [37].

In the UK context, CCC could aid in the decarbonisation of marine transport to reach the targets set in the UK Maritime 2050 strategy for 50\% reduction of GHG emissions by 2050 [38], whilst avoiding major design changes needed in order to switch fuel sources to ammonia or hydrogen as proposed in the Clean Maritime Plan [39]. This is an important sector in the UK economy since transport by sea involves around $95 \%$ of imports and exports, $25 \%$ of the energy supply, and $48 \%$ of food supply.

\subsubsection{Biogas Upgrading}

Upgrading biogas from waste such as manure [40], sewage sludge, or municipal waste to a higher methane content to produce 'biomethane' is of interest in countries with schemes that support its use as a vehicle fuel or for injection into the natural gas grid. Europe is the world's leading producer of biomethane, with 367 biomethane anaerobic digestion (AD) plants with a total upgrading capacity of $310,000 \mathrm{~m}^{3} / \mathrm{h}$ of raw biogas in 2014 [41].

Water scrubbing/absorption and amine-based chemical absorption are the most common upgrading technologies. Cryogenic/low-temperature upgrading technologies are still under development; however, they deliver a high methane purity with minimal methane loss $(<1 \%)$ and a high purity captured $\mathrm{CO}_{2}$ that usually shows up to $98 \%$ purity [42]. Though cryogenic distillation is the preferred method [42-44], it has been reported to consume a total specific energy of $1.79 \mathrm{MJ} / \mathrm{kg} \mathrm{CO}_{2}\left(0.35 \mathrm{kWh} / \mathrm{Nm}^{3}\right.$ of raw biogas) to produce biomethane at a $95.56 \%$ capture rate. Most efforts have focused towards the avoidance of dry ice formation caused by $\mathrm{CO}_{2}$ cryogenic separation due to potential operation problems caused by the blockage of pipes or other equipment [42]. However, a liquefaction process offers opportunities to deliver liquid biomethane (LBM) by freezing $\mathrm{CO}_{2}$ with a reduced energy consumption of $0.65 \mathrm{kWh} / \mathrm{Nm}^{3}$ of processed raw biogas, which is equivalent to the $5.2 \mathrm{MJ} / \mathrm{kg}$ of LBM that is produced [45].

Biogas composition mainly consists of methane and $\mathrm{CO}_{2}$, but it also contains trace contaminants such as $\mathrm{H}_{2} \mathrm{~S}$, organics, and siloxanes. The drying and precooling stages of CCC systems provide the conditions for the removal of benzene, whilst siloxanes are fully removed simultaneously during the $\mathrm{CO}_{2}$ removal step [46]. Alternatively to biogas upgrading, biogas could be employed directly in micro gas turbines, and the exhaust gases could be treated by post-combustion carbon capture technologies such as cryogenic carbon capture, which could lead to negative net emissions [47]. 


\subsection{Large-Scale Applications}

\subsubsection{Blue Hydrogen Production}

For low-carbon hydrogen production using fossil fuels, CCS technology is essential to produce the so-called 'blue' hydrogen in order to minimise $\mathrm{CO}_{2}$ emissions. High-purity hydrogen of $90-98 \%$ can be attained in large-scale hydrogen production plants through cryogenic distillation with hydrogen recovery of $96 \%$ [48]. The principle used here is based on the partial condensation of the impurities in the off-gas generated during hydrogen production at low temperatures. The steam methane reformer or refinery off-gas is a mixture of $\mathrm{CH}_{4}, \mathrm{CO}_{2}, \mathrm{CO}$, and other light hydrocarbons whose boiling points are relatively higher than that of hydrogen and therefore condense when the temperature is reduced significantly. Depending on the optimal operating conditions of the production plant, various refrigeration methods can be employed.

Joule-Thomson expansion of condensed hydrocarbon has been reportedly applied for refinery plant off-gas to meet the refrigeration requirement for cryogenic separation at an optimal feed pressure, gas rate, and hydrogen content of $2.8 \mathrm{MPa}, 5000 \mathrm{~m}^{3} / \mathrm{h}$, and less than $80 \%$, respectively [49]. Aasadnia, Mehrpooya and Ghorbani [50] used a Joule-Brayton propane unit and an auxiliary nitrogen unit to provide cold energy for the cryogenic separation of hydrogen from a feed gas containing nitrogen, methane, ethane, propane, and benzene in order to produce a high-purity hydrogen. The two refrigeration units, the Joule-Brayton propane and the nitrogen units, delivered refrigeration at $-155^{\circ} \mathrm{C}$ and $-40^{\circ} \mathrm{C}$, respectively. It was observed that the amount of hydrogen in the feed gas has an effect on the energy demand of the process in terms of energy required for compression and liquefying the nitrogen refrigerant. A $68 \%$ increase in the mole fraction of hydrogen in the feed gas inversely led to a $38 \%$ reduction in the energy consumed in the process. An increased pressure of the hydrogen-rich stream was reported to have increased the energy consumed by the propane unit and, consequently, the specific energy due to the resulting high temperature of the stream. There was also a rise in the cryogenic nitrogen that was required and an accompanying reduction in hydrogen recovery rate [50].

Conventional cryogenic distillation is a matured separation technology for hydrogen production just like pressure swing adsorption (PSA) technology. Although it benefits from higher hydrogen recovery compared to the PSA technology predominantly used in hydrogen production plants, its major drawback is the high energy demand required for hydrogen separation and purification leading to increased costs [48,51,52]. In addition, an initial step is necessary to remove water, $\mathrm{CO}, \mathrm{CO}_{2}$, and $\mathrm{H}_{2} \mathrm{~S}$ (if present) from the feed gas in order to prevent component holdup at low temperatures [53]. This has consequently led to a decline in the adoption of cryogenic distillation as a separation technology to purify hydrogen from reformer or refinery off-gas.

Recent efforts have progressed towards the combination of conventional cryogenic distillation with other hydrogen separation technologies such as PSA and membranes to improve the capture of $\mathrm{CO}_{2}$ generated during hydrogen production. Due to the increased energy demand required to obtain high-purity hydrogen from the cryogenic separation method, Agrawal, Auvil, DiMartino, Choe and Hopkins [54] proposed a combined membrane/cryogenic hybrid system. Cryogenic separation can improve hydrogen recovery, and the membrane system can achieve high-purity hydrogen when both systems are combined effectively. With refrigeration supplied by liquid nitrogen, a thermodynamic analysis of the hybrid cryogenic/membrane system was performed. It was observed that an increased concentration of hydrogen in the feed gas directly impacted the thermodynamic efficiency of the cryogenic process, with efficiency dropping from approximately $35 \%$ to $20 \%$ to produce hydrogen streams of purities of $70 \%$ and $96.5 \%$, respectively. The power requirement reported for the hybrid system was approximately $65 \%$ of that needed if the whole system were a completely cryogenic process. Although the hybrid system requires an additional membrane separation unit, the refrigeration for the cryogenic part has less refrigeration demand compared to an all-cryogenic system, thereby resulting in a lower capital cost for the hybrid system [54]. 
In their work, Kurokawa, Shirasaki and Yasuda [55] demonstrated a $\mathrm{CO}_{2}$ capture caused by cryogenic separation using a high hydrogen production efficiency membrane reactor off-gas, which produces hydrogen from natural gas, and $90 \% \mathrm{CO}_{2}$ was captured. The efficiency of the combined system was reported to be $78.6 \%$ with $\mathrm{CO}_{2}$ emissions reduced by $50 \%$ compared to conventional technology. A sensitivity analysis of the system conducted using a process simulator showed that the efficiency of the system falls with the decreasing temperature of the gas-liquid separator due to the high energy needed for the refrigeration unit to lower the phase separator temperature and subsequently improve the rate of $\mathrm{CO}_{2}$ recovery from the off-gas.

Lin, He, Sun, Kniep, Ng, Baker and Merkel [56] evaluated and conducted a technoeconomic analysis on a membrane/cryogenic hybrid system used for hydrogen production and $\mathrm{CO}_{2}$ capture. A total of three hydrogen production methods were considered: coal oxy-fired GE gasifier in an integrated gasification combined cycle (IGCC), a methane reformer/PSA process, and a coal air-blown IGCC power plant. The feed gas for the hybrid unit adopted for hydrogen purification and $\mathrm{CO}_{2}$ capture was the PSA off-gas generated by the methane reformer/PSA process and the syngas produced from both IGCC power plants. It was reported that the performance of the hybrid system depends on the $\mathrm{CO}_{2}$ capture target, process stream conditions, and membrane properties. In the methane reforming plant, it was revealed that the concentration of separated $\mathrm{CO}_{2}$ increases at a faster rate than the compressor when the $\mathrm{CO}_{2}$ capture rate is increased, resulting in a rise in the cost of refrigeration. The optimum capture rate was disclosed to be $80 \%$, above which there is a substantial increase in the power consumed and, subsequently, the cost of the produced $\mathrm{CO}_{2}$ liquid. However, a high concentration of $\mathrm{CO}_{2}$ in PSA off-gas as well as high $\mathrm{CO}_{2} / \mathrm{H}_{2}$ membrane selectivity was shown to have made cryogenic separation easier, leading to lower capital cost.

Similarly, Kim, Berstad, Anantharaman, Straus, Peters and Gundersen [57] optimised and compared three refrigeration methods for the cryogenic separation of $\mathrm{CO}_{2}$ from a membrane reactor off-gas (retentate) containing hydrogen, $\mathrm{CO}, \mathrm{CO}_{2}$, and $\mathrm{CH}_{4}$. The three separate cryogenic systems that use two-component refrigerants (composed of propane cycle and ethane cycle), single mixed refrigerant (comprising a mixture of methane, ethane, propane and butane), and Joule-Thomson expansion to liquify the reactor off-gas were simulated in Aspen HYSYS. Results indicated that the single mixed refrigerant design had the largest energy efficiency, while the Joules-Thomson system gave the highest power consumption due to the compression work required to increase the pressure of the retentate. It was, however, concluded that the Joule-Thomson system can be applied for retentate gas lean in $\mathrm{CO}_{2}$, while the two-component refrigerants system can be considered for $\mathrm{CO}_{2}$ rich gas retentate.

A hybrid system is already being demonstrated on an industrial scale. For instance, Air Liquide's CRYOCAP ${ }^{\mathrm{TM}}$ hydrogen technology has already been deployed on a small industrial scale and uses cryogenic technology and membranes to purify the $\mathrm{CO}_{2}$ present in PSA off-gas in a conventional steam methane reforming plant. In this concept, the reformer product stream is sent to the PSA to first separate the hydrogen. The PSA off-gas is then directed to the combined membrane-cryogenic distillation unit to separate and purify $\mathrm{CO}_{2}$ present in the PSA off-gas. There was a reported increase in hydrogen recovery, with more than $97 \%$ of $\mathrm{CO}_{2}$ from the syngas being captured [58,59]. In addition, ongoing research to perfect $\mathrm{CO}_{2}$ removal from flue gas makes use of their hybrid cryogenic technology, which combines PSA to produce a pre-concentrated $\mathrm{CO}_{2}$ stream and cryogenic method to further separate the concentrated $\mathrm{CO}_{2}$ stream from lighter gases [60]. When compared to amine technologies, CRYOCAP ${ }^{\mathrm{TM}} \mathrm{FG}$, for concentrated flue gases displayed a high $\mathrm{CO}_{2}$ capture rate of $90 \%$, whereas the amine-based $\mathrm{CO}_{2}$ capture technology exhibited a $69-74 \% \mathrm{CO}_{2}$ capture. Although demonstrated to be more economical than amine-based separation, this PSA-Cryogenic hybrid technology is not yet demonstrated at industrial scale and is rated at TRL 6. 
In more recent research considering unconventional cryogenic liquid technology, Yurata and his team [61] illustrated the feasibility of de-sublimating carbon dioxide before hydrogen liquefaction for $\mathrm{CO}_{2}-\mathrm{H}_{2}$ separation. In their approach, two de-sublimation columns were used simultaneously to subject the feed gas to a cold environment, where $\mathrm{CO}_{2}$ solidifies on the internal surface and subsequent heating to release $\mathrm{CO}_{2}$ and $\mathrm{H}_{2}$. Thereafter, the separate gas streams were liquified for storage and transportation. The energy demand of this process was compared to $\mathrm{H}_{2}-\mathrm{CO}_{2}$ separation technologies (membrane, PSA and MEA absorption) integrated with a liquefaction step downstream. It was proven that the de-sublimation method showed the lowest energy requirement. However, this process is not yet as widespread as the conventional cryogenic distillation.

\subsubsection{Direct Air Capture (DAC)}

The removal of $\mathrm{CO}_{2}$ from air was first commercialised in the 1950s as a means to pre-treat the air before undergoing cryogenic air separation [62]. In the late 1990s, $\mathrm{CO}_{2}$ removal from air (400 ppm $\left.\mathrm{CO}_{2}\right)$, now known as direct air capture (DAC), was explored to mitigate climate change, particularly from dispersed $\mathrm{CO}_{2}$ emitters or relatively small emitters [63]. DAC systems mostly involve solid sorbents or aqueous solutions. Aqueous solvents benefit from continuous operation but require costly regeneration systems. Carbon Engineering is one of the companies developing an aqueous DAC process; in their process, $\mathrm{CO}_{2}$ is first removed using a $\mathrm{KOH}$ solution, and the $\mathrm{CO}_{3}{ }^{-2}$ is then precipitated with $\mathrm{Ca}^{+2}$ to form $\mathrm{CaCO}_{3}$, which is then calcined to release the $\mathrm{CO}_{2}$ [62].

Direct air capture could also be achieved by using cryogenic separation via $\mathrm{CO}_{2}$ desublimation. Baxter, Baxter and Burt [27] have assessed the cryogenic potential on various $\mathrm{CO}_{2}$ compositions representing different sources of $\mathrm{CO}_{2}$. They reported that for a gas stream with a $14 \% \mathrm{CO}_{2}$ content on a dry basis, a temperature of approximately $-119{ }^{\circ} \mathrm{C}$ would be required, whilst a much lower $\mathrm{CO}_{2}$ content of $1 \%$ would only decrease the temperature to $-136{ }^{\circ} \mathrm{C}$ for a conservative $90 \% \mathrm{CO}_{2}$ capture efficiency. If their reported temperatures are extrapolated to $400 \mathrm{ppm} \mathrm{CO}_{2}$, a lower temperature of around $-157^{\circ} \mathrm{C}$ would be required. Thus, the cooling that is needed is achievable and less than what is necessary in air separation units (e.g., temperatures between $-183^{\circ} \mathrm{C}$ and $-196^{\circ} \mathrm{C}$ ).

\section{Challenges for Commercialisation}

\subsection{Technology Readiness Level (TRL)}

Cryogenic carbon capture is in the early stages of development. For example, Stirling coolers have only been tested at laboratory scale using solely $\mathrm{CO}_{2} / \mathrm{N}_{2}$ binary gas mixtures $[17,64]$. This system needs to be scale up to pilot or large-scale applications and be applied to different industrial $\mathrm{CO}_{2}$ emissions (such as power plants, cement, and steel, which represent different $\mathrm{CO}_{2}$ concentrations and the inclusion of impurities).

PMW Technology has demonstrated the capture step of the moving packed bed technology called A3C. The current technological readiness level of the A3C process is TRL 3, with a capture efficiency of $93 \%$ and higher [26]. Further development of the A3C process is expected to focus on the integration of the bed cooler, the capture column, and the bed sublimer into a combined continuous system.

Sustainable Energy Solutions (SES) has developed the Cryogenic Carbon Capture TM (CCC) technology that claims to reduce $\mathrm{CO}_{2}$ emissions from fossil-fuelled power plants by $95-99 \%$ [65]. SES has developed a direct-contact phase-change (DCPC) dryer for the simultaneous cooling and drying of the feed gas. The DCPC has been tested with a lithium chloride/water brine and a potassium acetate/water solution. For further cooling, they have used an ethanol/water solution or a methanol/water solution without freezing at the low temperatures that are needed [22]. More recently, SES has tested the CCC TM pilot demonstration unit to capture at least $95 \%$ of $\mathrm{CO}_{2}$ from a slipstream of 1 tonne per day (TPD) at the Cementos Argos' Roberta cement plant near Calera, Alabama and at the PacifiCorp Hunter coal-fired power plant near Castle Dale, Utah for nine months [65,66], which moves the technology to at least TRL 5. The company has plans to scale up the 
CCC-ECL process to a small commercial unit of 20-100 TPD after Chart Industries has acquired SES.

A technology that makes use of heat exchangers for the frosting and defrosting of $\mathrm{CO}_{2}$ followed by biomethane liquefaction is being commercialised by Cryo Pur. The process upgrades biogas into LBM (or bio-LNG). Their first commercial unit was installed in 2017 at Greenville Energy in Northern Ireland and operates at 3 tonnes of bio-LNG per day (i.e., treating $300 \mathrm{Nm}^{3} / \mathrm{h}$ raw biogas) [67]. Thus, this is the most advanced CCC process, with a TRL of at least 6.

\subsection{Competing Technologies}

It is out of the scope of this work to review all of the other alternative carbon capture methods and separation processes shown in Figure 1. Others have published in-depth reviews that can be found in [68-70]. Table 3 compares cryogenic carbon capture against more mature technologies, such as absorption and adsorption, highlighting their benefits and disadvantages.

In terms of hydrogen production, a comprehensive work that has gathered and compared the cost of hydrogen and capital costs for $\mathrm{H}_{2}$ production found that the costs of SMR with CCS are comparable or even lower than alternative methods such as gasification with and without CCS, nuclear thermolysis, and electrolysis [71]. All technological options are needed to reach the ambition target of net zero emissions by 2050, and CCS is indeed essential for the reduction of industrial emissions and hydrogen production.

Another emerging technology is sorption enhanced steam methane reforming (SESMR), a process intensification of steam methane reforming, which involves the in situ removal of $\mathrm{CO}_{2}$ produced during hydrogen production from a hydrocarbon source such as natural gas in a single reactor [72]. $\mathrm{CO}_{2}$ separation is usually done using a high-temperature solid sorbent such as calcium oxide $(\mathrm{CaO})$ which can be regenerated by temperature swing or pressure swing to produce pure $\mathrm{CO}_{2}$ stream [73]. With the sorbent capture cost going as low as USD 9- 11 per tonne of $\mathrm{CO}_{2}$ captured, a pure hydrogen stream of up to $99 \%$ can be attained $[74,75]$. This technology is already being demonstrated at the pilot stage. The BioZEG pilot plant developed by ZEG Power AS employs the concept of SE-SMR to produce hydrogen from hydrocarbon fuels. The plant, which integrates solid fuel oxide technology $\left(20 \mathrm{~kW}_{\mathrm{e}}\right)$ with hydrogen production $\left(30 \mathrm{~kW}_{\mathrm{H}}\right)$, is reported to have a potential of $100 \% \mathrm{CO}_{2}$ capture and $80 \%$ energy efficiency [76]. Hynor Lillestrøm have deployed a small-scale hydrogen production technology that currently integrates the sorption enhanced process for hydrogen production at their hydrogen station. The SER prototype capable of producing $12.5 \mathrm{Nm}^{3} / \mathrm{h}$ hydrogen from biogas at high carbon capture is currently operated by IFE Hynor in their lab [77]. The Gas Technology Institute (GTI) has successfully demonstrated a $71 \mathrm{~kW}_{\text {th }}$ integrated hydrogen production and carbon capture plant in the US. The facility was reported to achieve hydrogen purity of $\sim 92 \%$ and $90 \%$ $\mathrm{CO}_{2}$ capture [78]. For information on the wide range of hydrogen production technologies available and under development, please refer to other reviews [79-81]. 
Table 3. Characteristics of cryogenic carbon capture relative to other carbon capture technologies.

\begin{tabular}{|c|c|c|c|c|}
\hline Technology & Cryogenic Packed Bed & Adsorption & Absorption & Membrane \\
\hline Advantages & $\begin{array}{l}\text { - } \mathrm{CO}_{2} \text { can be } \\
\text { recovered at high } \\
\text { purity } \\
\text { - } \quad \text { apable of } \\
\text { operating at } \\
\text { atmospheric } \\
\text { pressure }\end{array}$ & $\begin{array}{ll}\text { - } & \text { Mature technology } \\
\text { - } & \text { Low cost of } \\
\text { sorbents } \\
\text { - } & \text { Sorbents can be } \\
\text { regenerated and } \\
\text { reused }\end{array}$ & $\begin{array}{l}\text { Most available } \\
\text { solvents are cheap } \\
\text { and suitable for } \\
\text { high-temperature } \\
\text { applications }\end{array}$ & $\begin{array}{ll}\text { - } & \text { High purity and } \\
\text { recovery of } \mathrm{CO}_{2} \\
\text { - } & \text { Short startup time } \\
\text { and low energy } \\
\text { requirement } \\
\text { - } \\
\text { Low-cost } \\
\text { separation of } \mathrm{CO}_{2}\end{array}$ \\
\hline Disadvantages & $\begin{array}{l}\text { - Uneconomical for } \\
\text { dilute } \mathrm{CO}_{2} \text { feed } \\
\text { streams } \\
\text { Feed composition } \\
\text { must be stripped } \\
\text { of water in order } \\
\text { to prevent ice } \\
\text { plugging } \\
\text { High energy } \\
\text { requirement due } \\
\text { to cooling }\end{array}$ & $\begin{array}{l}\text { High energy } \\
\text { penalty imposed by } \\
\text { high pressure } \\
\text { requirement for } \\
\mathrm{CO}_{2} \text { adsorption and } \\
\text { temperature for } \\
\text { sorbent } \\
\text { regeneration. } \\
\text { Periodic sorbent } \\
\text { regeneration easily } \\
\text { leads to quick } \\
\text { degradation of } \\
\text { sorbents and } \\
\text { subsequent } \\
\text { replacement }\end{array}$ & $\begin{array}{ll}\text { - } & \text { High energy } \\
\text { penalty due to } \\
\text { sorbent } \\
\text { regeneration } \\
\text { - } \quad \text { Large capital cost } \\
\text { resulting from } \\
\text { plant equipment } \\
\text { size and } \\
\text { high-performance } \\
\text { sorbent }\end{array}$ & 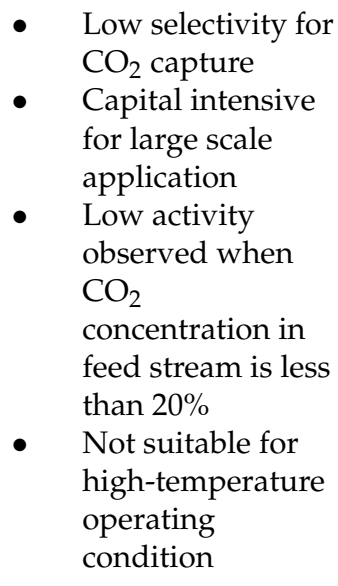 \\
\hline Scale & Small to large & Large & Large & Small to medium \\
\hline Capture Cost $/ \mathrm{tCO}_{2}$ & USD 55-130 & USD 50-150 & USD 40-100 & USD 15-55 \\
\hline $\mathrm{CO}_{2}$ recovery & $99.99 \%$ & $80-95 \%$ & $60-95 \%$ & $60-90 \%$ \\
\hline $\begin{array}{l}\text { Energy consumption } \\
\left(\mathrm{GJ} / \mathrm{tCO}_{2}\right)\end{array}$ & $2.4-5.2 \mathrm{GJ} / \mathrm{tCO}_{2}$ & $4-6 \mathrm{GJ} / \mathrm{tCO}_{2}$ & $2.3-9.2 \mathrm{GJ} / \mathrm{tCO}_{2}$ & $0.5-6 \mathrm{GJ} / \mathrm{tCO}_{2}$ \\
\hline Reference & {$[2,24,82]$} & {$[13,60,83,84]$} & [83-86] & {$[56,86,87]$} \\
\hline
\end{tabular}

\subsection{Incentives}

The need for CCS Research, Development, and Demonstration (RD\&D) policy is key, particularly for emerging technologies such as CCC systems. In the US, legislation in the Section 45Q tax credit (45Q) for carbon oxide sequestration defined the value of $\mathrm{USD} 35 / \mathrm{tCO}_{2}$ for EOR and non-EOR COx use and USD $50 / \mathrm{tCO}_{2}$ for $\mathrm{COx}$ secure geologic storage in 2018. More recently, the CCUS Tax Credit Amendments Act rised the 45Q credit value from USD 50 to USD 120 per metric ton for DAC plants that securely store $\mathrm{CO}_{2}$ in saline geologic formations and from USD 35 to USD 75/tonne for DAC facilities with $\mathrm{CO}_{2}$ storage in oil and gas fields [88].

Although the Netherlands is committed to reduce 14 Mton per year of $\mathrm{CO}_{2}$ by 2030 and recognises the substantial role of CCS to achieve their target, the country has capped CCS efforts to 7.2 Mton of $\mathrm{CO}_{2}$ capture to keep CCS as a transition technology particularly for difficult industries (e.g., cement). Thus, after 2035, there will be no more subsidies for fossil fuels, with a maximum subsidy of EUR 63/tonne of $\mathrm{CO}_{2}$ for CCS [89]. The company Carbon Collectors proposes collecting $\mathrm{CO}_{2}$ at customer site and then transporting it by ship to the nearest $\mathrm{CO}_{2}$ storage location [90].

For DAC, current studies have reported costs between USD 124 and USD 325 per metric tonne of $\mathrm{CO}_{2}$ removed from the atmosphere for the first million tons of installed capacity. The costs exclude $\mathrm{CO}_{2}$ compression and storage. For the US, support and policies for DAC are predicted to drop levelized costs through technological improvements, economies of scale, and mass production to between USD 85 and USD 261 per metric ton of $\mathrm{CO}_{2}$ at 7-9 MMt of capture capacity by 2030 [91]. 


\subsection{Challenges and Perspectives}

CCS technologies are key to achieving industrial decarbonisation and meet net zero carbon targets. Current CCS technologies have reported varying costs depending on the application, e.g., USD 40-60/tonne $\mathrm{CO}_{2}$ for the power sector and USD 200/tonne $\mathrm{CO}_{2}$ for the cement sector [92], and advances should decrease costs as CCS is more intensely deployed. It has been estimated that the current annual carbon capture of $40 \mathrm{Mt}$ of $\mathrm{CO}_{2}$, with 26 operating CCS facilities, should increase to $5.6 \mathrm{Gt}$ by 2050 to decarbonise not only the power sector but also hard to abate industries such as steel, cement, chemical industries [93]. The grand capacity that would be needed would create opportunities for projects of different scales and not just for foundation industries-one of the largest UK emitters with $50 \mathrm{Mt}$ of $\mathrm{CO}_{2}$ per year.

Due to the benefits of economies of scale, many countries, including the UK, USA, Canada, and Norway are creating hubs and clusters of concentrated industrial regions where shared compression, dehydration, transport, and storage will aid in decreasing unit costs and risks by synergies from multiple customers and suppliers of CCS networks [93].

For small-scale emitters, such as small enterprises or ships, novel and compact solutions are needed to minimise costs and space requirements. Cryogenic carbon capture could offer such solutions. In addition, CCC employed to upgrade biogas provides a means for negative emissions, and this application is more relevant when liquified biomethane and / or $\mathrm{CO}_{2}$ are the desired products. The amount of $\mathrm{CO}_{2}$ captured is suitable for decentralised solutions that are distant to CCS clusters as well as for $\mathrm{CO}_{2}$ use (CCU), e.g., for the synthesis of chemicals and production of building materials.

In order to assess the environmental effects of introducing CCS/CCU technologies, life cycle assessment (LCA) is a well-established tool for evaluating their impacts. So far, LCA for chemical absorption, oxy-combustion, chemical and calcium looping, and pre-combustion have been reported [94]. Thus, it is evident that emerging CCC technologies need LCA studies to be conducted without delay to support their relevance as low carbon solutions.

\section{Conclusions}

Carbon capture and storage is a technological option needed for the transition to the full elimination of fossil fuels and for the removal of carbon dioxide emissions for industries whose processes emit $\mathrm{CO}_{2}$. This review specifically covered cryogenic carbon capture (CCC) due to its benefits as a physical separation method. Different CCC methods that are mostly under development were presented, including their current challenges in deterring their commercialisation. It also offers an appraisal for selected feasible small- and large-scale CCC applications, including blue hydrogen production and direct air capture. This work provides an overview of the current status of CCC systems, including their technological readiness for CCC deployment and acknowledges competing technologies.

Author Contributions: C.F.-P.: conceptualization, writing-original draft preparation, writingreview and editing, funding acquisition; D.C. and C.U.: writing-original draft preparation, writingreview and editing. All authors have read and agreed to the published version of the manuscript.

Funding: C Font Palma thanks the fellowship supported by the Royal Academy of Engineering under the Leverhulme Trust Research Fellowship scheme (LTRF1920 \16 \18).

Institutional Review Board Statement: Not applicable.

Informed Consent Statement: Not applicable.

Data Availability Statement: All collected data are presented in the manuscript.

Conflicts of Interest: The authors declare no conflict of interest. The funders had no role in the design of the study; in the collection, analyses, or interpretation of data; in the writing of the manuscript, or in the decision to publish the results. 


\section{References}

1. BEIS. The Ten Point Plan for a Green Industrial Revolution-Building Back Better, Supporting Green Jobs, and Accelerating Our Path to Net Zero; HM Government: London, UK, 2020.

2. Song, C.; Liu, Q.; Deng, S.; Li, H.; Kitamura, Y. Cryogenic-based $\mathrm{CO}_{2}$ capture technologies: State-of-the-art developments and current challenges. Renew. Sustain. Energy Rev. 2019, 101, 265-278. [CrossRef]

3. Berstad, D.; Anantharaman, R.; Nekså, P. Low-temperature $\mathrm{CO}_{2}$ capture technologies-Applications and potential. Int. J. Refrig. 2013, 36, 1403-1416. [CrossRef]

4. Timmerhaus, K.D.; Reed, R.P. Cryogenic Engineering: Fifty Years of Progress; Springer: Berlin/Heidelberg, Germany, 2007. [CrossRef]

5. Kanbur, B.B.; Xiang, L.; Dubey, S.; Choo, F.H.; Duan, F. Cold utilization systems of LNG: A review. Renew. Sustain. Energy Rev. 2017, 79, 1171-1188. [CrossRef]

6. Smith, A.R.; Klosek, J. A review of air separation technologies and their integration with energy conversion processes. Fuel Process. Technol. 2001, 70, 115-134. [CrossRef]

7. Babar, M.; Bustam, M.A.; Ali, A.; Shah Maulud, A.; Shafiq, U.; Mukhtar, A.; Shah, S.N.; Maqsood, K.; Mellon, N.; Shariff, A.M. Thermodynamic data for cryogenic carbon dioxide capture from natural gas: A review. Cryogenics 2019, 102, 85-104. [CrossRef]

8. Ben-Mansour, R.; Habib, M.A.; Bamidele, O.E.; Basha, M.; Qasem, N.A.A.; Peedikakkal, A.; Laoui, T.; Ali, M. Carbon capture by physical adsorption: Materials, experimental investigations and numerical modeling and simulations-A review. Appl. Energy 2016, 161, 225-255. [CrossRef]

9. Maqsood, K.; Mullick, A.; Ali, A.; Kargupta, K.; Ganguly, S. Cryogenic carbon dioxide separation from natural gas: A review based on conventional and novel emerging technologies. Rev. Chem. Eng. 2014, 30, 453. [CrossRef]

10. Holmes, A.S.; Price, B.C.; Ryan, J.M.; Styring, R.E. Pilot tests prove out cryogenic acid-gas/hydrocarbon separation processes. Oil Gas. J. 1983, 81, 85-86.

11. Font-Palma, C.; Errey, O.; Corden, C.; Chalmers, H.; Lucquiaud, M.; Sanchez del Rio, M.; Jackson, S.; Medcalf, D.; Livesey, B.; Gibbins, J.; et al. Integrated oxyfuel power plant with improved $\mathrm{CO}_{2}$ separation and compression technology for EOR application. Process. Saf. Environ. Prot. 2016, 103, 455-465. [CrossRef]

12. Besong, M.T.; Maroto-Valer, M.M.; Finn, A.J. Study of design parameters affecting the performance of $\mathrm{CO}_{2}$ purification units in oxy-fuel combustion. Int. J. Greenh. Gas. Control. 2013, 12, 441-449. [CrossRef]

13. Mondal, M.K.; Balsora, H.K.; Varshney, P. Progress and trends in $\mathrm{CO}_{2}$ capture/separation technologies: A review. Energy 2012, 46, 431-441. [CrossRef]

14. Ali, A.; Maqsood, K.; Syahera, N.; Shariff, A.B.M.; Ganguly, S. Energy Minimization in Cryogenic Packed Beds during Purification of Natural Gas with High $\mathrm{CO}_{2}$ Content. Chem. Eng. Technol. 2014, 37, 1675-1685. [CrossRef]

15. Popov, D.; Fikiin, K.; Stankov, B.; Alvarez, G.; Youbi-Idrissi, M.; Damas, A.; Evans, J.; Brown, T. Cryogenic heat exchangers for process cooling and renewable energy storage: A review. Appl. Therm. Eng. 2019, 153, 275-290. [CrossRef]

16. Pan, X.; Clodic, D.; Toubassy, J. $\mathrm{CO}_{2}$ capture by antisublimation process and its technical economic analysis. Greenh. Gases Sci. Technol. 2013, 3, 8-20. [CrossRef]

17. Song, C.-F.; Kitamura, Y.; Li, S.-H.; Ogasawara, K. Design of a cryogenic $\mathrm{CO}_{2}$ capture system based on Stirling coolers. Int. J. Greenh. Gas. Control. 2012, 7, 107-114. [CrossRef]

18. Song, C.; Liu, Q.; Ji, N.; Deng, S.; Zhao, J.; Kitamura, Y. Advanced cryogenic $\mathrm{CO}_{2}$ capture process based on Stirling coolers by heat integration. Appl. Therm. Eng. 2017, 114, 887-895. [CrossRef]

19. Jensen, M.J.; Russell, C.S.; Bergeson, D.; Hoeger, C.D.; Frankman, D.J.; Bence, C.S.; Baxter, L.L. Prediction and validation of external cooling loop cryogenic carbon capture (CCC-ECL) for full-scale coal-fired power plant retrofit. Int. J. Greenh. Gas. Con. 2015, 42, 200-212. [CrossRef]

20. Fazlollahi, F.; Saeidi, S.; Safdari, M.-S.; Sarkari, M.; Klemeš, J.J.; Baxter, L.L. Effect of Operating Conditions on Cryogenic Carbon Dioxide Removal. Energy Technol. 2017, 5, 1588-1598. [CrossRef]

21. Baxter, L.; Lang, D. Cryogenic Carbon Capture Development; FE0028697; National Energy Technology Laboratory: Pittsburgh, PA, USA, 2016.

22. Baxter, L.L.; Baxter, A.; Bever, E.; Burt, S.; Chamberlain, S.; Frankman, D.; Hoeger, C.; Mansfield, E.; Parkinson, D.; Sayre, A.; et al. Cryogenic Carbon Capture Development; National Energy Technology Laboratory: Pittsburgh, PA, USA, 2019.

23. Tuinier, M.J.; Annaland, M.V.; Kramer, G.J.; Kuipers, J.A.M. Cryogenic $\mathrm{CO}_{2}$ capture using dynamically operated packed beds. Chem. Eng. Sci. 2010, 65, 114-119. [CrossRef]

24. Tuinier, M.J.; Annaland, M.V.; Kuipers, J.A.M. A novel process for cryogenic $\mathrm{CO}_{2}$ capture using dynamically operated packed beds-An experimental and numerical study. Int. J. Greenh. Gas. Con. 2011, 5, 694-701. [CrossRef]

25. Willson, P.; Lychnos, G.; Clements, A.; Michailos, S.; Font-Palma, C.; Diego, M.E.; Pourkashanian, M.; Howe, J. Evaluation of the performance and economic viability of a novel low temperature carbon capture process. Int. J. Greenh. Gas. Con. 2019, 86, 1-9. [CrossRef]

26. Cann, D.; Font-Palma, C.; Willson, P. Experimental analysis of $\mathrm{CO}_{2}$ frost front behaviour in moving packed beds for cryogenic $\mathrm{CO}_{2}$ capture. Int. J. Greenh. Gas. Con. 2021, 107, 103291. [CrossRef]

27. Baxter, L.; Baxter, A.; Burt, S. Cryogenic $\mathrm{CO}_{2}$ Capture as a Cost-Effective $\mathrm{CO}_{2}$ Capture Process; Researchgate: Berlin, Germany, 2009.

28. Khalilpour, R.; Mumford, K.; Zhai, H.; Abbas, A.; Stevens, G.; Rubin, E.S. Membrane-based carbon capture from flue gas: A review. J. Clean. Prod. 2015, 103, 286-300. [CrossRef] 
29. Hussin, F.; Aroua, M.K. Recent trends in the development of adsorption technologies for carbon dioxide capture: A brief literature and patent reviews (2014-2018). J. Clean. Prod. 2020, 253, 119707. [CrossRef]

30. Jensen, M. Energy Process Enabled by Cryogenic Carbon Capture; Brigham Young University: Proto, UT, USA, 2015.

31. IMO. IMO Action to Reduce Greenhouse Gas. Emissions from International Shipping; International Maritime Organization: London, $\mathrm{UK}, 2020$.

32. Balcombe, P.; Brierley, J.; Lewis, C.; Skatvedt, L.; Speirs, J.; Hawkes, A.; Staffell, I. How to decarbonise international shipping: Options for fuels, technologies and policies. Energy Convers. Manag. 2019, 182, 72-88. [CrossRef]

33. Lee, S.; Yoo, S.; Park, H.; Ahn, J.; Chang, D. Novel methodology for EEDI calculation considering onboard carbon capture and storage system. Int. J. Greenh. Gas. Control. 2021, 105, 103241. [CrossRef]

34. Feenstra, M.; Monteiro, J.; van den Akker, J.T.; Abu-Zahra, M.R.M.; Gilling, E.; Goetheer, E. Ship-based carbon capture onboard of diesel or LNG-fuelled ships. Int. J. Greenh. Gas. Control. 2019, 85, 1-10. [CrossRef]

35. Awoyomi, A.; Patchigolla, K.; Anthony, E.J. $\mathrm{CO}_{2} / \mathrm{SO}_{2}$ emission reduction in $\mathrm{CO}_{2}$ shipping infrastructure. Int. J. Greenh. Gas. Control. 2019, 88, 57-70. [CrossRef]

36. Willson, P. Evaluation of the Marine Application of Advanced Carbon Capture Technology; PMW Technology Limited, Department of Transport: London, UK, 2020.

37. Suki, W.; Aakre, S. TECO 2030 to Cooperate with Chart Industries, Inc. on Developing Marine Carbon Capture and Storage Solutions. 2021. Available online: https://ir.chartindustries.com/news-and-events/press-releases/news-details/2021/TECO-20 30-to-cooperate-with-Chart-Industries-on-developing-marine-carbon-capture-and-storage-solutions/default.aspx (accessed on 14 June 2021).

38. DfT. Maritime 2050. Navigating the Future; Department for Transport: London, UK, 2019.

39. DfT. Clean Maritime Plan; Department for Transport: London, UK, 2019.

40. Font-Palma, C. Methods for the Treatment of Cattle Manure-A Review. Carbon 2019, 5, 27. [CrossRef]

41. Scarlat, N.; Dallemand, J.-F.; Fahl, F. Biogas: Developments and perspectives in Europe. Renew. Energy 2018, 129, 457-472. [CrossRef]

42. Yousef, A.M.; El-Maghlany, W.M.; Eldrainy, Y.A.; Attia, A. New approach for biogas purification using cryogenic separation and distillation process for $\mathrm{CO}_{2}$ capture. Energy 2018, 156, 328-351. [CrossRef]

43. Hashemi, S.E.; Sarker, S.; Lien, K.M.; Schnell, S.K.; Austbø, B. Cryogenic vs. absorption biogas upgrading in liquefied biomethane production-An energy efficiency analysis. Fuel 2019, 245, 294-304. [CrossRef]

44. Pellegrini, L.A.; De Guido, G.; Langé, S. Biogas to liquefied biomethane via cryogenic upgrading technologies. Renew. Energy 2018, 124, 75-83. [CrossRef]

45. Baccioli, A.; Antonelli, M.; Frigo, S.; Desideri, U.; Pasini, G. Small scale bio-LNG plant: Comparison of different biogas upgrading techniques. Appl. Energy 2018, 217, 328-335. [CrossRef]

46. Font-Palma, C.; Lychnos, G.; Willson, P. Production of Biomethane From Agricultural Waste Using a Cryogenic Carbon Capture Process. In Proceedings of the 11th International Conference on Applied Energy, Västerås, Sweden, 12-15 August 2019.

47. Font-Palma, C.; Lychnos, G.; Nikpey Somehsaraei, H.; Willson, P.; Assadi, M. Comparison of Performance of Alternative Post Combustion Carbon Capture Processes for a Biogas Fueled Micro Gas Turbine. In Proceedings of the ASME Turbo Expo 2020: Turbomachinery Technical Conference and Exposition, Virtual Conference, 21-25 September 2020.

48. Grashoff, G.J.; Pilkington, C.E.; Corti, C.W. The Purification of Hydrogen-A Review of the Technology Emphasising the Current Status of Palladium Membrane Diffusion. Platinum Metals Rev. 1983, 27, 157.

49. Agrawal, R.; Herron, D.M.; Rowles, H.C.; Kinard, G.E. Cryogenic Technology. In Kirk-Othmer Encyclopedia of Chemical Technology; John Wiley \& Sons, Inc.: Hoboken, NJ, USA, 2003. [CrossRef]

50. Aasadnia, M.; Mehrpooya, M.; Ghorbani, B. A novel integrated structure for hydrogen purification using the cryogenic method. J. Clean. Prod. 2021, 278, 123872. [CrossRef]

51. Zornoza, B.; Casado, C.; Navajas, A. Advances in Hydrogen Separation and Purification with Membrane Technology. In Renewable Hydrogen Technologies: Production, Purification, Storage, Applications and Safety; Elsevier B.V.: Amsterdam, The Netherlands, 2013; pp. $245-268$.

52. Peramanu, S.; Cox, B.G.; Pruden, B.B. Economics of Hydrogen Recovery Processes for the Purification of Hydroprocessor Purge and Off-Gases. Int. J. Hydrogen Energy 1999, 24, 405-424. [CrossRef]

53. Du, Z.; Liu, C.; Zhai, J.; Guo, X.; Xiong, Y.; Su, W.; He, G. A Review of Hydrogen Purification Technologies for Fuel Cell Vehicles. Catalysts 2021, 11, 393. [CrossRef]

54. Agrawal, R.; Auvil, S.R.; DiMartino, S.P.; Choe, J.S.; Hopkins, J.A. Membrane/cryogenic hybrid processes for hydrogen purification. Gas. Sep. Purif. 1988, 2, 9-15. [CrossRef]

55. Kurokawa, H.; Shirasaki, Y.; Yasuda, I. Energy-efficient distributed carbon capture in hydrogen production from natural gas. Energy Procedia 2011, 4, 674-680. [CrossRef]

56. Lin, H.; He, Z.; Sun, Z.; Kniep, J.; Ng, A.; Baker, R.W.; Merkel, T.C. $\mathrm{CO}_{2}$-selective membranes for hydrogen production and $\mathrm{CO}_{2}$ capture-Part II: Techno-economic analysis. J. Membr. Sci. 2015, 493, 794-806. [CrossRef]

57. Kim, D.; Berstad, D.; Anantharaman, R.; Straus, J.; Peters, T.A.; Gundersen, T. Low Temperature Applications for $\mathrm{CO}_{2}$ Capture in Hydrogen Production. In Computer Aided Chemical Engineering; Elsevier B.V.: Amsterdam, The Netherlands, 2020; Volume 48, pp. 445-450. 
58. Pichot, D.; Granados, L.; Morel, T.; Schuller, A.; Dubettier, R.; Lockwood, F. Start-up of Port-Jérôme CRYOCAPTM Plant: Optimized Cryogenic $\mathrm{CO}_{2}$ Capture from $\mathrm{H}_{2}$ Plants. Energy Procedia 2017, 114, 2682-2689. [CrossRef]

59. Terrien, P.; Lockwood, F.; Granados, L.; Morel, T. $\mathrm{CO}_{2}$ Capture from $\mathrm{H}_{2}$ Plants: Implementation for EOR. Energy Procedia 2014, 63, 7861-7866. [CrossRef]

60. Rodrigues, G.; Raventos, M.; Dubettier, R.; Ruban, S. Adsorption Assisted Cryogenic Carbon Capture: An Alternate Path to Steam Driven Technologies to Decrease Cost and Carbon Footprint. In Proceedings of the 15th Greenhouse Gas Control Technologies Conference 2020 (GHGT-15), Virtual Conference, 15-18 March 2021.

61. Yurata, T.; Lei, H.; Tang, L.; Lu, M.; Patel, J.; Lim, S.; Piumsomboon, P.; Chalermsinsuwan, B.; Li, C. Feasibility and sustainability analyses of carbon dioxide-Hydrogen separation via de-sublimation process in comparison with other processes. Int. J. Hydrogen Energy 2019, 44, 23120-23134. [CrossRef]

62. Keith, D.W.; Holmes, G.; Angelo, D.; Heidel, K. A Process for Capturing $\mathrm{CO}_{2}$ from the Atmosphere. Joule 2018, 2, $1573-1594$. [CrossRef]

63. Lackner, K.; Ziock, H.-J.; Grimes, P. Carbon Dioxide Extraction from Air: Is It an Option. In Proceedings of the 24th International Technical Conference on Coal Utilization and Fuel Systems, Clearwater, FL, USA, 8-11 March 1999; Los Alamos National Lab.: Los Alamos, NM, USA, 1999.

64. Song, C.; Kitamura, Y.; Li, S. Energy analysis of the cryogenic $\mathrm{CO}_{2}$ capture process based on Stirling coolers. Energy 2014, 65, 580-589. [CrossRef]

65. SES. Sustainable Energy Solutions. 2020. Available online: https://sesinnovation.com (accessed on 20 July 2021).

66. Frankman, D.; Burt, S.; Beven, E.; Parkinson, D.; Wagstaff, C.; Roberts, W.; Baxter, L. Recent Cryogenic Carbon Capture ${ }^{\mathrm{TM}}$ Field Test Results. In Proceedings of the 15th International Conference on Greenhouse Gas Control Technologies, GHGT-15, Abu Dhabi, United Arab Emirates, Virtual Conference, 15-18 March 2021.

67. CryoPur. Two Years of Operation for the Cryo Pur Plant at Greenville Energy. Available online: http://www.cryopur.com/en/ news/two-years-of-operation-greenville/ (accessed on 18 June 2021).

68. Anwar, M.N.; Fayyaz, A.; Sohail, N.F.; Khokhar, M.F.; Baqar, M.; Khan, W.D.; Rasool, K.; Rehan, M.; Nizami, A.S. CO 2 capture and storage: A way forward for sustainable environment. J. Environ. Manag. 2018, 226, 131-144. [CrossRef] [PubMed]

69. Leung, D.Y.C.; Caramanna, G.; Maroto-Valer, M.M. An overview of current status of carbon dioxide capture and storage technologies. Renew. Sustain. Energy Rev. 2014, 39, 426-443. [CrossRef]

70. Boot-Handford, M.E.; Abanades, J.C.; Anthony, E.J.; Blunt, M.J.; Brandani, S.; Mac Dowell, N.; Fernández, J.R.; Ferrari, M.-C.; Gross, R.; Hallett, J.P.; et al. Carbon capture and storage update. Energy Environ. Sci. 2014, 7, 130-189. [CrossRef]

71. Edwards, R.L.; Font-Palma, C.; Howe, J. The status of hydrogen technologies in the UK: A multi-disciplinary review. Sustain. Energy Technol. Assess. 2021, 43, 100901. [CrossRef]

72. Carvill, B.T.; Hufton, J.R.; Anand, M.; Sircar, S. Sorption-Enhanced Reaction Process. AICHE J. 1996, 42, 2765-2772. [CrossRef]

73. Di Giuliano, A.; Gallucci, K. Sorption Enhanced Steam Methane Reforming Based on Nickel and Calcium Looping: A Review. Chem. Eng. Process. Process Intensif. 2018, 130, 240-252. [CrossRef]

74. Ji, G.; Yang, H.; Memon, M.Z.; Gao, Y.; Qu, B.; Fu, W.; Olguin, G.; Zhao, M.; Li, A. Recent advances on kinetics of carbon dioxide capture using solid sorbents at elevated temperatures. Appl. Energy 2020, 267, 114874. [CrossRef]

75. Wang, Y.; Memon, M.Z.; Seelro, M.A.; Fu, W.; Gao, Y.; Dong, Y.; Ji, G. A Review of $\mathrm{CO}_{2}$ Sorbents for Promoting Hydrogen Production in the Sorption-Enhanced Steam Reforming Process. Int. J. Hydrogen Energy 2021, 46, 23358-23379. [CrossRef]

76. Andresen, B.; Norheim, A.; Strand, J.; Ulleberg, Ø.; Vik, A.; Wærnhus, I. BioZEG-Pilot plant demonstration of high efficiency carbon negative energy production. Energy Procedia 2014, 63, 279-285. [CrossRef]

77. Meyer, J.; Mastin, J.; Pinilla, C.S. Sustainable hydrogen production from biogas using sorption enhanced reforming. Energy Procedia 2014, 63, 6800-6814. [CrossRef]

78. Mays, J. One Step Hydrogen Generation through Sorption Enhanced Reforming; Gas Technology Institute: Golden, CO, USA. [CrossRef]

79. Pareek, A.; Dom, R.; Gupta, J.; Chandran, J.; Adepu, V.; Borse, P.H. Insights into renewable hydrogen energy: Recent advances and prospects. Mater. Sci. Energy Technol. 2020, 3, 319-327. [CrossRef]

80. Antonini, C.; Treyer, K.; Streb, A.; van der Spek, M.; Bauer, C.; Mazzotti, M. Hydrogen production from natural gas and biomethane with carbon capture and storage-A techno-environmental analysis. Sustain. Energy Fuels 2020, 4, 2967-2986. [CrossRef]

81. Acar, C.; Dincer, I. Review and evaluation of hydrogen production options for better environment. J. Clean. Prod. 2019, 218, 835-849. [CrossRef]

82. Tuinier, M.J.; Hamers, H.P.; Annaland, M.V. Techno-economic evaluation of cryogenic $\mathrm{CO}_{2}$ capture-A comparison with absorption and membrane technology. Int. J. Greenh. Gas. Con. 2011, 5, 1559-1565. [CrossRef]

83. Yu, C.H.; Huang, C.H.; Tan, C.S. A review of $\mathrm{CO}_{2}$ capture by absorption and adsorption. Aerosol. Air Qual. Res. 2012, 12, 745-769. [CrossRef]

84. Theo, W.L.; Lim, J.S.; Hashim, H.; Mustaffa, A.A.; Ho, W.S. Review of pre-combustion capture and ionic liquid in carbon capture and storage. Appl. Energy 2016, 183, 1633-1663. [CrossRef]

85. Vega, F.; Baena-Moreno, F.M.; Gallego Fernández, L.M.; Portillo, E.; Navarrete, B.; Zhang, Z. Current Status of $\mathrm{CO}_{2}$ Chemical Absorption Research Applied to CCS: Towards Full Deployment at Industrial Scale. Applied Energy 2020, 260, 114313. [CrossRef] 
86. Merkel, T.C.; Lin, H.; Wei, X.; Baker, R. Power plant post-combustion carbon dioxide capture: An opportunity for membranes. J. Membr. Sci. 2010, 359, 126-139. [CrossRef]

87. Brunetti, A.; Scura, F.; Barbieri, G.; Drioli, E. Membrane technologies for $\mathrm{CO}_{2}$ separation. J. Membr. Sci 2010, 359, 115-125. [CrossRef]

88. Bright, M. Surveing the US Federal CCS Policy Lanscape in 2021; Global CCS Institute: Melbourne, Australia, 2021.

89. SDE. Stimulation of Sustainable Energy Production and Climate Transition (SDE++). Available online: https://english.rvo.nl/ subsidies-programmes/sde (accessed on 15 June 2021).

90. Jorgensen, A.-M. Industrial $\mathrm{CO}_{2}$ Reduction and Climate Policy-Carbon Collectors. 2020. Available online: https://carboncollectors. $\mathrm{nl} /$ (accessed on 15 June 2021).

91. Larsen, J.; Herndon, W.; Grant, M.; Marsters, P. Capturing Leadership_Policies for the US to Advance Direct Air Capture Technology; Rhodium Group, LLC: New York, NY, USA, 2019.

92. SAPEA. Novel Carbon Capture and Utlisation Technologies: Research and Climate Aspects; Science Advice for Policy by European Academies: Berlin, Germany, 2018.

93. Pag, B.; Turan, G.; Zapantis, A. Global Status of CCS 2020; Global CCS Institute: Melbourne, Australia, 2020.

94. Cruz, T.T.; Perrella Balestieri, J.A.; de Toledo Silva, J.M.; Vilanova, M.R.N.; Oliveira, O.J.; Ávila, I. Life cycle assessment of carbon capture and storage/utilization: From current state to future research directions and opportunities. Int. J. Greenh. Gas. Control. 2021, 108, 103309. [CrossRef] 